\title{
The usage of political euphemisms in the english and uzbek press languages
}

\section{Nilufar FAYZIYEVA ${ }^{1}$}

National University of Uzbekistan named after Mirzo Ulugbek

\begin{tabular}{l} 
ARTICLE INFO \\
\hline Article history: \\
Received July 2021 \\
Received in revised form \\
20 July 2021 \\
Accepted 15 August 2021 \\
Available online \\
15 September 2021 \\
\\
\hline Keywords: \\
euphemism words, \\
political, \\
types of euphemism words, \\
usage of political \\
euphemism words in Uzbek \\
and English.
\end{tabular}

\begin{abstract}
This article investigates why individuals utilize euphemism words in political wrangle about and whether that exertion is beneficial. In expansion to the numerous euphemism words that are acknowledged by for all intents and purposes everyone, the political cleared out has its claim set of euphemism words related with political rightness, whereas the political right has its possess set connected to energetic rightness.

2181-1415/C) 2021 in Science LLC.

This is an open access article under the Attribution 4.0 International (CC BY 4.0) license (https://creativecommons.org/licenses/by/4.0/deed.ru)
\end{abstract}

\section{Siyosiy efemizmlardan ingliz va o'zbek tillaridagi matbuotda foydalanish}

\footnotetext{
Kalit so'zlar:

evfemizm so'zlar,

siyosiy,

evfemizm so'zlar turi,

o'zbek va ingliz tillarida

siyosiy evfemizm

so'zlarining ishlatilishi.
}

\begin{abstract}
ANNOTATSIYA
Ushbu maqolada nima uchun odamlar siyosiy munozarada evfemizm so'zlarini ishlatishi va bu harakat foydali yoki yo'qligi o'rganildi. Ko'pchilik evfemizm so'zlarni kengaytirishda, har kim xohlagan maqsadda tan oladigan bo'lsada, sof siyosiy so'zlar siyosiy haq bilan bog'liq bo'lgan evfemizm so'zlarga ega, siyosiy huquq esa o'z kuchiga ega.
\end{abstract}

\footnotetext{
${ }^{1}$ PhD student, Faculty of Foreign Philology National University of Uzbekistan named after Mirzo Ulugbek. Tashkent, Uzbekistan.
} 


\section{Использование политических эфемизмов в английском и узбекском языках прессы}

\author{
Ключевые слова: \\ слова эвфемизма, \\ политические, \\ типы слов эвфемизма, \\ употребление слов \\ политического эвфемизма \\ в узбекском и английском \\ языках.
}

\begin{abstract}
АННОТАЦИЯ
В этой статье исследуется, почему люди используют слова-эвфемизмы в политических спорах, и полезно ли это усилие. В дополнение к многочисленным эвфемистическим словам, которые признаются всеми для всех намерений и целей, политическое очищение имеет свой набор эвфемистических слов, связанных с политической правотой, в то время как политическое право имеет свой набор, связанный с энергетической правотой.
\end{abstract}

Political wrangle about within the advanced world is outlandish without memorizing a list of euphemism words, and there is no deficiency of open slander for those who conversation around certain themes without utilizing them. In expansion to the numerous euphemism words that are acknowledged by for all intents and purposes everyone, the political cleared out has its claim set of euphemism words related with political rightness, whereas the political right has its possess set connected to energetic rightness. Euphemism words tend to serve as signals of political-tribal enrollment, but moreover as implies to persuade irresolute voters to back one approach or the other. Abusing the other political tribe's euphemism words can indeed offer assistance a candidate gets chosen President. This article investigates why individuals utilize euphemism words in political wrangle about and whether that exertion is beneficial.

The word "euphemism" refers to a neutral expression that replaces an incorrect expression to make the text more euphonic or closed. Politicians, sociologists and advertisers are calling for such a replacement.

Euphemism is a neutral word or definition used to change impurity or misconception. The term speaks to us in ancient Greek and means "good speech" in translation. They are used for the following purposes: a) in politics, to deceive or manipulate the truth; b) replacing blasphemous or misleading words from ruthless areas in printed materials.

The need for such allegories arose from the time of the taboo of language, when it was forbidden to express the names of their gods or dangerous diseases, and some other phenomena of nature. Later, in Christian times, the word "unclean" changed the remembrance of the devil. The role of euphemisms has grown tremendously in the circle of believers whose moral rules require subtle allegories. Today, such literary synonyms successfully replace unsuccessful words with another partner.

The use of euphemisms is explained by the desire to avoid conflicts, misunderstandings, to maintain the morality of the conversation, to create a comfortable environment for the interlocutor. Euphemisms have historically evolved and improved, and they can be divided into two groups: 1) Accepted; 2) Stable.

In the social sphere, euphemism is very popular, used to hide the truth. Political corrections require the avoidance of words that harm people's feelings and dignity, so the art of euphemism of politicians rises to a higher level. In the Uzbek language: a) diplomatic negotiations; b) pressure from the authorities or penal authorities; c) military development and secrets; d) activities of law enforcement agencies; e) inter-communal relations. 
The functions of political euphemism in the media are the same, and they apply to more appropriate words: 1) the work of government officials: "vakolatli organlar" "federal xizmatlar"; 2) description of military conflicts: "hududni tozalash" - "halokat"; 3) presentation of economic schemes: "moliyaviy piramida" - "pul ayg'oqchilari"; 4) notaries of national or social groups: "doimiy yashash joyi bo'lmagan shaxs" "boshpanasiz", "afro-amerikalik" - "negro"; 5) names of foreign policy measures: "Birikimli dunyo", "Amerikaning buyrug'i".

Besides, politically correct euphemisms also include the following words: a) mitigating age discrimination: "keksa odam" - "qarigan yoshdagi odam"; b) for people with disabilities or mental retardation: "nogironlar, aqli zaiflar" - "maxsus ehtiyojga ega bo'lganlar"; c) not "dirty" professions, but to hide people's hatred of them: "sut sog'ish operatori" - "milkmaid"; d) distracts from unpleasant events in the economy: "ommabop bo'lmagan choralar" - "soliq o'sishi".

Euphemism words alter over time. Harvard analyst Steven Pinker named this etymologist advancement the "euphemism word treadmill" and, over twenty a long time prior, contended that supplanting ancient terms with unused ones was likely motivated by the untrue hypothesis that dialect impacts considerations, a idea that has been long disparaged by cognitive researchers. Pinker depicted how those who board the euphemism word treadmill can never step off:

People invent new "polite" words to refer to emotionally laden or distasteful things, but the euphemism becomes tainted by association and the new one that must be found acquires its own negative connotations.

Few political talks about are as perplexed with euphemism words as migration. The precise lawful term "illegal alien", which was once said without political predisposition and is presently nearly solely utilized by nativists, was supplanted with "illegal immigrant" which was supplanted by "undocumented immigrant" and, in rarer cases, "unauthorized immigrant". Silly terms like "border infiltrator" and "illegal invader" have not caught on however. Advocates of the modern term "undocumented immigrant" contend that no one can be unlawful, so the term "illegal immigrant" is wrong as well as discourteous. Of course, no one is undocumented either, as undocumented either, as they fair need the certain particular archives for legitimate residency and work. Numerous have driver's licenses, charge cards, library cards, and school distinguishing pieces of proof which are valuable reports in particular settings but not about so much for movement. "Misdocumented immigrant" would be superior in case the objective was exactness, but the objective appears to be to alter people's conclusions on enthusiastic points by changing the words they utilize.

Within the migration wrangle about, the euphemism word treadmill can some of the time run in turn around and really make political dialect harsher. This "cacophemism cliff" turned "birthright citizenship" into "anchor baby" and "liberalized immigration" into "open borders".

In the long run, venturing onto the euphemism word treadmill can appear like a fool's errand. As Pinker clarifies, people's sentiments toward the supplanted term are only exchanged to the euphemism word since we all have concepts that we utilize words to depict but we don't utilize words to design modern concepts. The concept-to-word cognitive generation handle as it were influences the sound of the yield, not its meaning. 
Surrounding - "Undocumented Immigrants" or "Illegal Aliens". Not all is misplaced for exercisers on the euphemism word treadmill. They fair need to lower their desires and be fulfilled with surrounding political talk, instead of the impetuous objective of changing concepts with words. Surrounding may be a mental method that can impact the recognition of social marvels, a political or social development, or a pioneer. Investigate in political brain research has appeared that surrounding works through making certain convictions available in memory upon presentation to a specific outline. Once certain convictions are enacted through the instrument of surrounding, they influence all the ensuing data preparing. Any case of framing's control to influence recognition is that suppositions almost a Ku Klux Klan rally shift depending on whether it is surrounded as an open security or free discourse issue.

Surrounding can direct open conclusion in inverse bearings of the political range. The "undocumented immigrant" outline will conjure distinctive convictions from the "illegal alien" outline. Particularly, the previous is portraying the issue as a bureaucratic government issue harrowing standard migrants. The last mentioned outlines it as a law and arrange issue with remote nationals. These two euphemism words, in spite of the fact that implied to speak to the same concept, do so in numerous ways that pass on distinctive messages and will pull the recipients of the outlines completely different headings. Most individuals feel sensitivity toward those caught up in a brutal bureaucratic bog but are much less thoughtful to criminals.

Taking after this rationale, an approach proposition titled "path to citizenship for undocumented immigrants" is getting to draw in more back than "amnesty for illicit aliens." Both "path to citizenship" and "amnesty" here cruel legalization. In any case, the term "legalization" suggests that there has been something illicit almost that bunch of individuals, an affiliation which many proponents need to dodge. "Path to citizenship" could be a much gentler outline that conjures positive emotions. On the other side of the talk about, "legalization" has been supplanted with "amnesty," which incorporates a more negative meaning. Defenders and clients of the term "amnesty" are emphasizing that it could be a acquit for an offense instead of a settle of a bureaucratic issue. "Pathway to citizenship" is additionally in some cases supplanted by "earned legalization" or "comprehensive migration change". These two expressions bring up considerations about legality and reform, both of which are far more cognitively charged than "path to citizenship" and therefore less likely to be used by supporters of such policies.

Dog Whistles and the Threat Frame: "Extreme Vetting", "Illegal Invader", and "Anchor Baby".

Euphemism words can offer assistance legitimize something else biased talk. Consider "extreme vetting", a state that has been alluded to as a euphemism word for "discrimination against Muslims." Utilizing this specific euphemism word makes a difference one finish two objectives. To begin with, it makes a difference partitioned oneself from outright separation based on religion or national beginning, which is imperative since earlier investigate in political science has appeared that individuals are progressively touchy to social allure and so are unwilling to precise obtusely preferential convictions since it has gotten to be less socially worthy to do so. Hence, concealing such bias beneath an unbiased euphemism word is or maybe valuable in that respect. Moment, it still passes on the generally message of antagonistic vibe to the group of onlookers responsive to such talk - too known as a dog whistle. Therefore, you'll be able to show your claim convictions and interface the gathering of people with comparative convictions without coming over as being gruffly partial. 
A to some degree comparable thought is behind the utilize of the "illegal invader" term, which goes indeed encourage by conjuring a danger outline. Dangers may well be capable instruments since, once debilitated, individuals tend to overestimate the chance and back arrangements that minimize the danger no matter how little it really is. Risk outlines contrarily inclination audience members against this bunch.

A critical impact of danger outline euphemism words is that they can dehumanize and join negative demeanors to certain bunches. Consider the euphemism words "anchor baby" and "catch and release". "Anchor baby" stands for children born to remote nationals who are in infringement of their migration status whereas on U.S. soil.

Those children have programmed citizenship beneath the U.S. Structure. Such children are called "anchor babies" in arrange to highlight the thought that they are utilized by their guardians to secure them remain within the nation in spite of the fact that that seldom really happens. The term dehumanizes both the guardians and their children by depicting these people through affiliation with an inanimate object, the "anchor," which the as it were reason for the presence of the children is to resolve the parent's issue with migration law. Risk outlines moreover expand to other criminal action related to migrants.

This article investigates the hypothetical base of utilizing euphemism words in Uzbek and English as instruments of impact. In spite of the fact that there's a few great inquire about into these issues related to immigration, it could be a field crying out for more test and experimental request. Research facility tests with human subjects may affirm the adequacy of particular euphemism words as primes or outlines. Since such thinks about are frequently criticized for their outside legitimacy, a follow-up consider that combines substance examination of pertinent media with supposition surveys that appear changes in states of mind might too be valuable.

An underexplored plausibility is how euphemism words and outlines influence political talk about by spreading disarray. Individuals usual to the term "illegal immigrant" to depict foreign-born people who are right now unlawfully dwelling within the Joined Together States might at first fall flat to respond as contrarily to the term "undocumented immigrant" just since they don't know what it implies. As before long as they know what it implies, in any case, the negative sentiments they relate with "illegal immigrant" would likely connect to the term "illegal alien". Another is how euphemism words construct dividers around political tribes and avoid them from talking to each other, in this way extending approach divisions that avoid middle-ground arrangements.

\section{REFERENCES:}

1. Ismatullayev N. Hozirgi o'zbek tilida efemizmlar. Nomzodlik dissertatsiyasi. Toshkent. - 1963.

2. Begmatov E.A. Nomlar va odamlar. - T.: Fan, 1966.

3. Omonturdiyev A. O'zbek nutqining evfemik asoslari. Toshkent. - 1997.

4. Алтаев С. Эвфемизмы в туркменском языке, Ашхабад, 1955.

5. Ахмедов А.К., Табу и эвфемизмы в казакском языке, Алматы. - 1973.

6. Боровой Л.Б. “Путь слова” М., 1963.

7. Видлак С.Н. “Проблема эвфемизма на фоне теории языкого поля” М., 1967.

8. Джаббаров Н.М., Табу и эвфемизмы в азербайжанском языке, Баку, 1972.

9. Исматуллаев Н. Эвфемизмы в современном узбекском языке: автореф. дис... канд. филол.наук. Т.: 1963. 